\title{
THE NETWORK STRUCTURE OF HUNGARIAN BUSINESS CLUSTERS
}

This article investigates the attitudes to inter-firm co-operation in Hungary by analysing a special group of business networks: the business clusters. Following an overview of cluster policy, a wide range of selfproclaimed business clusters are identified. A small elite of these business networks evolves into successful, sustainable innovative business clusters. However, in the majority of cases, these consortia of interfirm co-operation are not based on a mutually satisfactory model, and as a consequence, many clusters do not survive in the longer term. The paper uses the concepts and models of social network theory in order to explain, why and under what circumstances inter-firm co-operation in clusters enhances the competitiveness of the network as a whole, or alternatively, under what circumstances the cluster remains dependent on Government subsidies. The empirical basis of the study is a thorough internet research about the Hungarian cluster movement; a questionnaire based expert survey among managers of clusters and member companies and a set of in-depth interviews among managers of self-proclaimed clusters. The last chapter analyises the applicability of social network theory in the analysis of business networks and a model involving the value chain is recommended. ${ }^{1,2}$

Keywords: inter-firm co-operation, clusters, business networks

The data sources of the research were as follows. We have reviewed the professional literature on Hungarian clusters and on cluster policy and examined the webpages of 75 Hungarian cluster organisations which maintain a strong presence on the internet. Subsequently we carried out a fieldwork, which included:

- a questionnaire based expert survey among managers of clusters and member firms with the participation of 22 respondents,

- personal structural interviews made at cluster organizations and cluster member firms: 10 case studies were prepared,

- participation in professional conferences and cluster meetings.

\section{Summary of findings}

The study investigated the population of business networks defining themselves as clusters, and the internal structure of their inter-organisational and inter-firm linkages. The conceptual framework of social network theory was applied to a wide range of empirical data collected about real existing clusters.
In Hungary there are more than 180 business networks, which define themselves as clusters. This number is is more than the combined number of self-defined cluster organisations in all neighboring countries of Hungary. At the same time the Hungarian population of cluster organizations is characterised by high of birth rate and a high level of mortality. In many consortia the level of activity and the content of inter-firm cooperation vary in time. The vast majority of cluster organizations have been organised in order to implement occasional projects and between these intervals of activity the business network is inactive. However, from the population of such cluster organisations eventually a highly visible, active and successful elite of clusters has emerged, especially in the pharmaceutical, biotechnology, environment, industry, and information and communication technology sectors.

Cooperation within clusters is motivated by commercial relationship, by the existence and utilization of a common knowledge base for innovation. Companies and other organizations establishing clusters have launched various projects to jointly utilise some common resource, to participate in the value chain, to gain 
new markets or to jointly enforce their interests vis-ávis some local or the central government.

Cluster self-definition and cohesion among members. The self defined identity and mission of the clusters is of utmost importance. Clusters that do not adequately define the scope and form of cooperation within the cluster are vulnerable. Lack of a coherent cluster identity may reduce the professionalism of cooperation and and lead to loss of trust among the firms. Among the investigated clusters, segmentation may develop either if certain distinct sub-groups evolve based on a particular industrial/professional culture or if some of the larger member companies of the cluster develops supplier linkages with only a subset of members. This is especially true for the classical manufacturing sector where the cluster frequently contains several competitor member firms. Mutual trust is more likely to erode in times of crisis or in case of dwindling external resources.

The role of regional/sectoral affiliation in cluster identity. The majority of investigated clusters affiliates itself with a particular region of Hungary. In particular, approximately two-thirds of clusters consider themselves as regionally focused: in such cases the majority of the members are located in the same region. Companies of the environmental and energy industry, the IT and telecom sector, biotech and healthcare sectors and some selected branches of manufacturing (plastics, textiles, wood, automotive products) have established clusters with a strong professional affiliation. Clusters with strong sectoral/professional binding frequently demonstrate no affiliation to a specific region. Clusters organized on a sectoral/professional basis are more efficient and more sustainable than those organized on a strong regional basis.

Network centralization. Clusters dominatedy by one or two "flagship" companies are called centralized clusters. Such networks are either subcontracting hierarchies or networks organised around a joint research and development projects, where members have unequal access to know-how. Centralized cluster formation can be found primarily in the IT and biotechnology sectors. In most cases, the fact that some companies within the network have a monopoly in the particular know how or finances can explain their dominant position.

Clusters are called segmented, if some smaller groups, "cliques" are formed within the network, within which the cooperation is satisfactory, but linkages among the cliques are weak, occasional or completely non-existent. Segmented clusters have been observed, but not very often. Among the investigated clusters, segmentation may develop, if certain distinct sub-groups evolve the based on a particular industrial/ professional culture or if some of the larger member companies of the cluster develops supplier linkages with only a subset of members.

Network characteristics is a major factor in the success or decline of a cluster. Consortia built around a "flagship" firm have more chance of success, especially if the member companies are integrated by a specific professional culture. Segmented clusters as a rule are less sustainable than clusters free of cliques. Clusters may flexibly adapt to changes in market conditions, to variations of the business cycle or of the business environment by creating new sub-groups within the network, which are capable to launch new projects, to re-use the results of previous projects. Indeed, the ability to re-organise the network structure is the most important criterion of effective adaptation within a particular cluster.

Innovation. Innovation activities are important elements of cluster efficiency. In many cases research and development is not implemented by the cluster organization itself, but by one of its members, e.g. by a university department. The fact that a research institute or a university is a member of the cluster does not guarantee in itself innovation activities within the cluster; indeed, in many cases the opposite is observed. About half of the clusters participate in innovation diffusion, even if no cluster member has taken part in the development of the particular innovative product, technology or service. Innovations embodied in some product or technology have been observed much more frequently than innovations of abstract, less tangible nature, such as organizational and service innovations.

Cluster policy and subsidies. Cluster policy can be conceived as part of regional development policy, enterprise development policy or innovation policy. The main aim of cluster policy is to promote the development and operation of collaborative networks among (a) companies and (b) among companies and other organizations, such as professional associations, R \& $\mathrm{D}$ institutes. The adverse side effects of cluster subsidies are much smaller than the effects of direct subsidies given to individual firms. The latter strategy often gives artificial advantages to particular companies by picking the winners of competition.

Cluster accreditation is an innovative element of Hungarian cluster policy, which improves the competitive position of promising clusters. Accreditation is also necessary in order to distinguish those Hungarian clusters that are true clusters in the internationally accepted sense from other networks, such as temporary consortia and project organisations. 
Donor dependence. The majority of clusters operating in Hungary are products of cluster policy. Government co-financing offered for start-up projects institutionalising clusters and for support to investment projects are the main drivers of the creation and development of clusters. The biggest challenge of cluster policy is to select those projects that can be sustained without government interventions in the long term. According to the expert survey, only about half of the investigated clusters would be able to operate successfully on the long term without subsidies. The other half of the respondents presume that their clusters are more or less dependent on the extent of subsidies: in the absence of subsidies these clusters could either offer far fewer services to members, or their life expectancy would be shorter, or in some cases even the network could be dissolved. Overall, the more subsidy dependent is a cluster, the smaller is its perceived sustainability. The above problems of sustainablity and donor-dependence could be reduced by applying the best international practices of cluster development policies.

\section{Research questions}

Theoretical background. International and Hungarian experiences have shown that inter-firm co-operation is motivated by tangible advantages that can be easily analysed within rational profit-maximising logic and also by intangible advantages such as the enhancement of social capital. Inter-firm linkages go far beyond buyer-purchaser relationships and are shaped by entrepreneurial culture and trust and the ability and know-how of initiating and managing co-operation. ${ }^{3}$ Inter-firm co-operation and competition are not antagonistic to each other. Rather, co-operation is an equally important ingredient of company strategy and may be crucial in achieving success on markets. On global, national and local markets not only individual firms compete with each other; frequently it is the competitiveness of entire networks that decides the outcome of business decisions. ${ }^{4}$

Aims. The research is aimed at the description of those tangible and intangible factors that determine the strength and stability of inter-firm networks and in particular, of clusters in Hungary. The findings are used to evaluate a class of business networks: self-proclaimed clusters in Hungary, and also to assess the impacts of cluster policy in Hungary.

The research questions are related to the network structure and dynamics of Hungarian clusters.

-What is the role of strong vs. weak inter-firm linkages in business clusters? Which factors motivate or de-motivate inter-firm co-operation? What is the role of entrepreneurial culture in enhancing the willingness and ability of firms to co-operate with each other?

- What is the professional content of inter-firm co-operation? (e.g. Joint marketing and market development, Joint innovation and development, joint tendering, etc.) Are these clusters predominantly focused on jointly obtaining inputs (materials, components, trained workforce, finance), or rather on jointly putting their outputs on the market (marketing co-operation)? How can we characterise the predominant inter-firm linkages in the sample of clusters? Are these trade linkages, innovation linkages, knowledge flow linkages, subcontracting linkages?

- What is the network structure of Hungarian clusters? Why are some clusters more concentrated than others? Why are some clusters more segmented than others?

- How do typical firms manage the portfolio of inter-firm relations in a particular company? Are costs and benefits of inter-firm ties measurable, and if yes, how? Are these costs and benefits transparent?

- What is the inter-dependence between (a) the structure of clusters and (b) the growth, competitiveness and sustainability of these networks? What conclusions can be made about the impact of linkage strength on competitiveness? Under what circumstances are certain network types optimal? How does network structure react to external factors such as financial crises, increasing uncertainity of market conditions?

- Does the value chain play a role in organising interactions within the cluster? If yes, what is this role?

- What are the major components of a culture of inter-firm co-operation in Hungary?

Regarding the network aspects of innovativeness, we have investigated the following research questions:

- Which types of clusters are innovative? Do clusters/member firms perceive themselves as innovative? If yes, are these their own innovations or rather innovations absorbed from outside.

- How does innovation spread within and through the cluster? (Via subcontracting agreements, by the force of joint investments, training courses, via labour mobility, etc.)

- Where does the know-how necessary for innovation originate from? In particular, which types of 
clusters rely on exogenous, which types of clusters rely on endogenous sources of knowledge, as measured by the role of research organisations, universities, etc. in the cluster.

Regarding cluster policy, we have investigated the following research questions:

- Do subsidies have an impact on creating and strengthening inter-firm linkages, promoting a culture of cooperation?

- To what extent are existing clusters products of spontaneous market forces, and to what extent are they created by subsidies? To what extent are the investigated clusters subsidy-dependent?

- What are the best practices for supporting interfirm networking?

- What are the advantages of supporting inter-firm networking as opposed to other forms of subsidies?

Methodological aims. Another, equally important aim of this paper is to present a feasible empirical methodology for the investigation of real existing clusters. A data collection and analytical frame is presented which is suitable to test a set of hypotheses derived from network research ${ }^{5}$, and takes into consideration data availability in the specific Hungarian landscape of entrepreneurial networks and clusters.

\section{Previous research and evaluation on business networks and clusters in Hungary}

Since the mid 1990s the conditions of co-operative behaviour of companies, the culture of inter-firm co-operation, more generally the institutional framework of inter-organizational co-operation was the subject of a wide range of research efforts in Hungary. ${ }^{6}$ This empirical evidence has demonstrated that inter-firm linkages in Hungary have an important role in enhancing competitiveness and that inter-organisational co-operation is facilitated by entrepreneurial culture and trust.

Cluster development measures and the resulting business clusters have been repeatedly evaluated both on their own right and in the framework of wider policy areas such as SME development, innovation policy and regional development.

In 2003 an interview-based survey on cluster development was implemented. The evaluation was initiated by the Hungarian Ministry of Economy and Transport among subsidized Hungarian regional clusters and business networks. ${ }^{7}$ The aim of the research was to assess the impacts of a Government sponsored subsidy pro- gramme called „Széchenyi Plan” of 2001 which among other entities has supported regional clusters as well. The research used the "organisational" definition of clusters, according to which a group of companies and other organisations is a cluster if they have entered and to some extent formalized their co-operation which is aimed at enhancing their joint competitiveness. Moreover, in this approach only those groups are considered which explicitly identify themselves as clusters.

The above mentioned 2003 research investigated 20 case study clusters, based on interviews with cluster managers, with local, central government institutions and trade associations which have played an instrumental role in developing clusters. Regional clusters were defined as networks of co-operating companies, SME-support institutions, local governments, trade associations and technology transfer institutions such as University departments or technology consulting firms. In most cases clusters were project organisations with no legal identity. Their activities consisted of training, transfer of know-how in order to become subcontractors, joint quality management, spreading information on European Union standards, product family marketing, regional marketing, interest representation, organisation of conferences, joint participation on fairs, organisation of business meetings, preparation of application and tender documents for various subsidised programmes financed by the Hungarian Government and / or the European Union.

The interviewed clusters of 2003 were only weakly institutionalised, the cluster organisation possessed no legal status, therefore the clusters as such could not be parties of a contract. Most of them had a temporary character and have used the organisational framework of an existing company or enterprise support institution. ${ }^{8}$ The functions of clusters have significantly overlapped with the activities of professional and trade organisations, chambers of commerce, industrial parks, incubator houses and SME and regional development organisations. A loosely, vaguely defined cluster concept has contributed to the inter-changeability of these organisational identities.

Although the 2003 study has revealed some weaknesses of the Government policy towards clusters, it has recommended intensifying the support of inter-firm networking rather than supporting individual firms, in order to avoid the proliferation of interventionist subsidy schemes.

In 2005 a business survey on small business networks was implemented. This rigorous questionnairebased survey ${ }^{9}$ on small business entrepreneurial networks has shown that more than half of Hungarian 
small businesses were involved in some regular interfirm co-operation. Inter-firm co-operation appeared in various forms, such as outsourcing - subcontracting, franchising, regional and/or sectoral clustering, joint ownership and co-ownership. The exchange between the participating firms took many forms, such as

- regularly buying products and services from each other,

- inter-firm bartering,

- exchange of information, provision of consultancy,

- exchange of tools and machines,

- providing occasional credits to each other,

- referring clients to each other,

- co-operation in purchasing from third parties,

- co-operation in sales to third parties,

- joint development of new products/technologies/ services.

A substantial number of these linkages went far beyond the regular exchange of favors and were formalised in contracts. Medium sized companies claimed to be more frequently members of some inter-firm co-operation than smaller and micro companies. Companies selling their products to other firms or to public bodies, and exporting companies were more frequently parts of some inter-firm co-operation than companies selling only for the local population. Companies that were members of a network were more optimistic and more growth oriented than non-member (i.e. "isolated", "atomised") companies.

In 2006 an international comparative evaluation of cluster policies $^{10}$ included the assessment of the Hungarian cluster program since 2001 in its scope. This evaluation was made in the context of other regional policy measures such as the creation of industrial parks and EU structural fund programming. The evaluators found that in spite of some clear and spectacular cases of successful clusters, overall cluster policies were not sufficiently integrated with regional economic strategies and decision makers did not always apply stringent test on what network could be considered a cluster initiative.

In 2007 an evaluation of the Hungarian cluster movement ${ }^{11}$ stressed that in Hungary typical clusters are not built up in a bottom-up style, rather such networks are initiated by local subsidiaries of multinationals and facilitated by government measures in a top-down fashion. While the first clusters were subcontracting pyramides, later other purposes of networking appeared such as the pooling of procurements and increasingly the joining of forces in lobbying for regu- latory advantages and applying for government subsidies. Cluster organisations have experimented with a wide range of services offered for members, such as the spreading of benchmarking information, facilitation of market access, consultancy in tender procedures, training, project management, facilitation of spin-off companies, etc. In spite of this, a typical cluster was not self sustaining, since incomes generated from these services covered in general only one-third of its expenses. In typical clusters co-operation was driven only by the cluster organisation, whereas the spontaneous launching of new inter-firm co-operations with no intervention of the cluster center was in most cases between companies that have nurtured ties already before entering the cluster.

In 2008-2010 a mapping exercise has revealed the spatial-industrial agglomerations of Hungarian firms. A series of research projects ${ }^{12}$ in 2008 to 2010 tackled the issue of communication, knowledge transfer, and cooperative actions among Hungarian companies. One of the main objectives was to identify, map and evaluate the Hungarian clusters with the help of regionally desaggregated company census data. The research used the "spatial-industrial" concept of clusters, defining clusters as a group of companies engaged in similar activities located in close proximity to each other. ${ }^{13}$ The geographic mapping of these "spatial-industrial" clusters was based on annual census-type data of Hungarian firms, compiled from financial statements associated with tax reporting. The geographic density of firms of the same sector was measured with the help of Gini coefficients by using employment data disaggregated into the 20 spatial administrative units of Hungary and 37 branches (sectors) of the industry.

The study has identified 48 industrial clusters in Hungary and statistically evaluated their size, level of specification, innovativeness and export activity. Strong clusters were found in the automotive, food processing and information technology sectors. Based on international experiences it was hypothesized that cooperation of Hungarian companies relies heavily on close, regular contact and face-to-face interaction, that significant synergies stem from co-location of cooperating market actors and that therefore the spatial concentration of actors, the geographic agglomeration of industrial activity in the same branch can improve competitiveness. The authors have clearly distinguished between vertical and horizontal types of co-operation, the former identified as becoming part of global value chains as regular suppliers, the latter interpreted as cooperation of predominantly small companies in industrial clusters in order to compete with larger multinational companies. 
Also in 2008 the so-called "Pólus Programme" was evaluated in a series of studies ${ }^{14}$. The Pólus programme was an ambitious support scheme of the Hungarian Government to facilitate the birth and development of industrial clusters. The authors have followed the life cycle of clusters by observing their subsequent stages of development such as attracting founding member companies, creating a cluster organization, obtaining finance, offering services for members by the management, achieving financial sustainability through membership and service fees and achieving the so-called "critical mass" of firms which is necessary for the long term viability of cooperation. Evidence was presented to support the thesis that inter-firm trust is a necessary condition of long term co-operation, of network sustainability. The study has recommended good practices for reducing mistrust and "short-termism", to improve entrepreneurial culture.

\section{The evolution of cluster policy in Hungary}

Subcontracting development. Inter-firm linkages have been supported in Hungary already since the early 1990s, when the government launched its subcontracting development programme. ${ }^{15}$ In this programme small and medium sized companies were supported by financial subsidies, by supported business consultancy services ${ }^{16}$ and by marketing instruments, e.g. by free access to subcontracting roadshows and fairs. The aim of the programme was to increase the ability of beneficiary firms to become subcontractors of multinational manufacturing companies located in Hungary. The first Hungarian clusters were communities of subcontracting firms, organised in most cases around local subsidiaries of multinational companies.

Cluster subsidy schemes. After 2000 the respective subsidy schemes and business support services widened their target group and the support of entrepreneurial networks and clusters started, first with an experimental character. Subsidy schemes were and still are the most important instruments of cluster policy. Between 2001 and 2011 these programmes have been repeated and significantly improved ${ }^{17}$, although after 2010 the associated budgetary sources have significantly decreased.

Supported business networks have received on average the equivalent of 100 to 150 thousand EUR as a "cluster start-up subsidy" in order to establish cluster organisations and to elaborate competitiveness-enhancing projects. At a later stage, some of these business networks were beneficiaries of several, consecutive investment subsidies of a much higher magnitude, originating from various subsidy schemes.
As a result of the above programs many consortia were supported; which partly explains the high number of cluster organisations in the country. In 2012 the Government owned programme organisation which is responsible for cluster policy, MAG Zrt collected data on more than 180 cluster organisations in Hungary. ${ }^{18}$

Before 2010 cluster policy was closely associated with regional development policy, because cluster subsidies were tied to the development of certain preferred cities, also called "poles". From 2012 the regional focus of cluster policy has diminished. The official doctrine of development policy is conceptualised as "clusterbased" instead of "based on poles"19. However, cluster support remains an integral part of regional policy, because a substantial part - although not the full amountof cluster related subsidies are to be obtained through regionally defined subsidy schemes.

In 2011/12 a wide range of existing Hungarian clusters received subsidies from Government or European funds. There is wide agreement among experts that public financial support is crucially important in establishing and sustaining the clusters, with special respect to innovative ones, in which companies work together with each other as well as with universities and research organisations.

Cluster accreditation. The support of Hungarian clusters was facilitated by a Government run scheme of accreditation. Self-proclaimed clusters that apply for subsidies are evaluated by a designated body. The evaluation is based on quantitative and qualitative criteria, including

- the level/extent/depth of cooperation within the cluster,

- the prevalence of joint research/development/innovation projects,

- the volume of services jointly purchased by cluster member companies,

- the volume of jointly financed common marketing actions of cluster member companies,

- the number, size and turnover of member companies, and

- the dynamics of the above indicators, etc.

As a result of the above accreditation procedure, clusters are classified in four stages according to their level of development, ranging from "clusters in initial phase" through "developing clusters", "accredited clusters" up to the so-called "innovation clusters". ${ }^{20}$ The title "Accredited Innovation Cluster" is valid for 2 years, is renewable and offers a better access to subsidies. In 2011-2012 in Hungary 26 accredited clusters were functioning. These clusters are distributed among the following sectors/branches (Table 1): 
Table 1

The distribution of "Accredited Innovative Clusters" by sectors / branches ${ }^{21}$ Hungary, 2011 22

\begin{tabular}{|l|c|}
\hline Informatics & 6 \\
\hline Business services & 4 \\
\hline Health & 3 \\
\hline Environment & 3 \\
\hline Construction & 2 \\
\hline Education & 2 \\
\hline Energy & 1 \\
\hline Alimentary (food) industry & 1 \\
\hline Wood and furniture & 1 \\
\hline Logistics & 1 \\
\hline Plastic industry & 1 \\
\hline Tourism & 1 \\
\hline Total & 26 \\
\hline
\end{tabular}

It is foreseen that cluster accreditation procedure as a major instrument of cluster policy will survive but it will be aligned with the so called European Cluster Excellence Initiative (ECEI). ${ }^{23}$

\section{Main statistical features of the investigated cluster population}

Number of clusters. In Hungary there are more than 180 business networks that call themselves clusters. However, not all of these consortia are active and properly institutionalised cluster organisations; in fact some of them are inactive project organisations. The number of self-proclaimed organised clusters in Hungary is more than the combined number of cluster organisations in all of its neighbouring countries. ${ }^{24}$

Size of clusters in terms of the number of members.

A typical cluster consists of 20 to 30 members, but in extreme cases the consortium may range from 5 to 150 members.

Legal form of cluster members. While the membership of typical clusters consists mostly of small and medium sized companies, approximately half of the investigated clusters have a few members from the public sector: in most cases university chairs or research organisations, sometimes local governments, chambers and associations.

Size of member companies. Within a particular cluster most members (about 75\%) are small and medium sized companies with a strong focus on small and micro companies. In particular, two-thirds of the member companies of the investigated clusters reported a turno- ver of less than 1 million EUR. A narrower range of cluster members (about 20\%) are bigger firms, in some cases even multinationals.

Ownership of cluster member firms. Most of the company members are privately owned, but a narrow range of cluster member companies are partly or fully owned by the public sector, e.g. by local governments.

Regional focus. A wide range of clusters define themselves with a strong regional focus. Such networks have chosen as their names a region of the country (e.g. "Pannon" referring to Western Hungary or Southern Great Plain), followed by a sectoral denomination (such as informatics, or transport development). However, in most sectors it is almost impossible to restrict cluster membership to companies located in a particular region. In particular, the linkages of clusters in the environment protection sector reach well over the regional borders. About two-thirds of the investigated clusters are regionally concentrated in the sense that at least two thirds of the members of the cluster are located in the same county. ${ }^{25}$ All regions of the country are represented in the investigated cluster population.

Sectoral focus. A wide range of the investigated clusters identify themselves with a strong professional/ sectoral focus, with or without a reference or allegiance to a particular region of Hungary. The following major sectors are represented in Table 2.

Table 2

Distribution of investigated clusters by profession/sector. Clusters with strong Internet visibility $(\mathrm{N}=75)$ Hungary, 2012

\begin{tabular}{|l|c|}
\hline \multicolumn{1}{|c|}{ Profession / Sector } & $\begin{array}{c}\text { Number of } \\
\text { clusters in } \\
\text { the database }\end{array}$ \\
\hline Environmental and energy industries & 21 \\
\hline Information and communication technology & 13 \\
\hline Manufacturing of industrial goods (plastic, \\
textile, automotive parts and wood) & 11 \\
\hline Health industry & 9 \\
\hline Logistics & 4 \\
\hline Tourism & 3 \\
\hline Food / alimentary industry & 3 \\
\hline Business services, including consultancy & 3 \\
\hline Local investment promotion & 2 \\
\hline Construction industry & 2 \\
\hline Business network for joint purchasing & 2 \\
\hline Education & 2 \\
\hline Total & 75 \\
\hline
\end{tabular}

Source: web research of the authors 


\section{Clusters in particular sectors}

Clusters in particular sectors can be characterised as follows.

- IT sector. Clusters based on information and communication technology are composed of companies offering IT systems integration, web design, and public database management. In this sector a frequently mentioned aim of co-operation is to contribute to jointly implemented, Government co-financed projects, by sharing specialised available knowledge. Therefore cluster member firms frequently delegate their expert employees to other cluster member companies in order to work in such projects. The expert survey has reinforced that - compared with other sectors - companies from the IT sector

- rely much less on the cluster in selling their products and services,

- report about much less conflicts among cluster members,

- describe their cluster as less concentrated,

- assess themselves as most innovative,

- stress much more the importance of Government subsidies in keeping the cluster together.

- Environment protection industry and biotechnology sector. Clusters based on environmentally friendly technologies are typically networks of companies offering products and technologies of renewable energy, in particular the building and customisation of energy generating equipment from solar, biological or recycled sources. In some cases this equipment is imported, in other cases the appliances are developed in Hungary. The expert survey has reinforced that - compared with other sectors - in the environment protection and biotechnology sector cluster member companies

- are more export oriented and rely more on the cluster in selling their products and services,

- describe their inter-firm network as more concentrated and more segmented,

- have higher expectations as of the co-operation, and are less contented with the development of the cluster,

- rely much more on external stakeholders in their innovation activity.

- Classical manufacturing sector. The sample contains a wide range of clusters identifying themselves strongly with metal parts production, with wood based (furniture) industry or with some other manufacturing activity. The expert survey has reinforced that - compared with other sectors - companies from the classical manufacturing sector
- describe their sector as very competitive, so much so that competition effectively and strongly limits the extent to which clustering / networking is possible,

- describe their cluster as less concentrated,

- assess themselves as less innovative, but if they enter into innovation activity, they rely much more on themselves than on external stakeholders,

- report about significantly more conflicts and debates among their members.

- Business services sector. There is a wide range of clusters where the members offer consultancy and business services such as project evaluation, tender application preparation, financial risk assessment, PR, marketing, real estate development and others. The expert survey has revealed that - compared to clusters of other sectors - networks in this sector are

- characterised with weaker linkages,

- the level of institutionalisation of these clusters is somewhat weaker, and

- the level of sustainability, as perceived by their members is on a lower level than in case of clusters based on more tangible commodities.

\section{Clusters as networks: the structure of linkages}

Strength of inter-firm ties. Most clusters in Hungary are inherently loose networks. While other networks such as those based on franchise and joint ownership (holdings) are stable, involve core company functions and high financial stakes, in many clusters co-operation extends only to the implementation of a single project, or to various projects involving a particular non-core company function.

Network concentration of clusters and the issue of a dominant "flagship" company. The expert survey and the in-depth interviewers have explicitly asked the respondents, whether in their respective clusters there is a dominant company, which would strongly influence cluster strategy and decisions. Within the investigated clusters there are large differences in terms of firm size and bargaining power. However, these big differences in bargaining power lead only in certain cases to the emergence of a network with a strong centrum, e.g. a flagship company. About half of the experts have perceived their cluster as concentrated (centralised) in this sense, as opposed to the other half of the respondents.

- Centralised clusters are to be found frequently in case of a subcontracting hierarchies, or if the consortium has embarked on a joint investment project with unequal access to innovation know-how. 
- In decentralised networks in most cases the scope of co-operation extends only to a narrow, "noncore" segment of company functions (e.g. joint purchasing), and the partners are more or less equal in their co-operation.

Clusters with dominant, "hub" or "flagship" type companies are more frequently found in the IT and biotechnology industries, than in other sectors. In most cases a dominant position within the network can be explained by a monopolistic access of a single company to development finances and/or to know-how. Clusters with dominant members - as opposed to clusters without such "flagships" - are also characterised by stronger than average export activity. Moreover, members of centralised clusters report about stronger than average internal conflicts, both hidden and open, but also about an elaborated conflict resolution mechanism within the cluster.

Network segmentation / cliques in the cluster. The expert survey and the in-depth interviews have revealed that clusters with a segmented network structure represent a minority. In such cases co-operation is satisfactory within several cliques, but weak or nonexistent between these groups of companies. As a rule, segmentation within a cluster may evolve

- if the cluster involves well identifiable subgroups of companies with characteristically different industrial cultures, or

- if the cluster is organised around some strong companies which are more interested to cooperate with their traditional subcontractors, which are members of the cluster as well, than with other cluster members.

\section{Cluster management, its challenges and instruments}

Cluster institutionalisation. In Hungary there are various ways to institutionalise cluster management. The following organisational solutions are available and have been used in the practice:

- the cluster establishes an autonomous limited liability company, a non-profit company, a foundation or an association specifically for the purpose of cluster management,

- a particular member of the cluster, usually a firm with strong administrative capacities provides the necessary services to run the cluster,

- the cluster is established and run by a consulting firm, specialised on cluster management and tender application know how. In many cases such consultant firms simultaneously manage a wide range of other clusters as well.
Cluster finances. Cluster organisations are financed from the following sources:

- membership fees,

- consultant fees: the management organisations obtains fees from the members in exchanges for the consultancy services provided,

- donations provided by the member organisations,

- government subsidies,

- profits obtained from business activities,

- commissions charged for business agency activities.

On average, only one-third of expenses are covered by the services of the cluster organisation. ${ }^{26}$

Subsidized projects: the driving force of co-operation. Cluster subsidies represent a major motivation in creating inter-firm co-operations. Within a particular network the first experiences in obtaining external funds and managing subsidised projects create a know how which can be used in obtaining support for new, much bigger projects. Frequently the cooperation between cluster members lasts only for the duration of a single project. However even one bigger sized subsidized project can be sufficient to accumulate networking capabilities, to facilitate the inter-firm spreading of knowledge and to learn how to cooperate informally activities in a network without any sub-organisation linkages.

Trust and informal management. Since clusters are inherently loose organisations, cluster managers do not have access to strong coercion instruments. Their power within the network is weak, frequently relying on informal, verbal agreements. Therefore cluster managers must rely mostly on their ability to convince members, to handle conflicts. Clusters rely very strongly on inter-personal trust. For this reason, any changes in the leadership of a member company (e.g. inheritance) may lead to a serious setback of the co-operation willingness and capability. Cluster managers having experiences in managing chambers of commerce, associations and other organisations based on inter-firm cooperation have a better chance to be successful than those managers whose previous experiences were limited to managing tasks within a single ${ }^{27}$ company.

\section{A self-evaluation of cluster success or failure}

The web analysis ( $\mathrm{N}=75$ clusters) has confirmed the variability of clusters with respect to success and growth. The typical cluster is well functioning but in most cases its growth is moderate or even stagnating. This overall impression has been confirmed by the enumeration, visibility and analysis of joint projects, cluster news and cluster organised events. 
According to the expert survey ( $\mathrm{N}=22$ clusters), the clusters of the IT and of the environmental industry sectors are perceived by the respondents as those with the healthiest growth dynamics. On the other hand, most respondents from the classical manufacturing sector were reporting stagnation or decline.

The expert survey has also provided information on how the managers of clusters and member firms evaluate their respective cluster by using the criteria generally used in case of project evaluation. ${ }^{28}$ Since the sample consisted both of successful and stagnating clusters, their opinions were divided. In general, respondents were more satisfied with (a) the relevance and (b) impact of their respective cluster projects, as compared with their satisfaction regarding (c) efficiency, (d) effectiveness and (e) sustainability (Table 3.).

\section{Innovation in clusters}

When applying for Government subsidies, most clusters highlight the innovative nature of their planned activities. In the expert survey $(\mathrm{N}=22)$ about half of the cluster member firms identified themselves as "somewhat" or "very" innovative. Respondents to the expert survey were unanimous in that joint innovation activity is an important ingredient of the effectiveness and efficiency of the cluster. The personal interviews have also reinforced that those clusters where innovation was the main mission of the cluster, were much more confident than their less innovative counterparts regarding their efficiency and sustainability.

Existence of a joint innovation, research or development project. The most important criterion of innovati-

Table 3

\section{Ratings of cluster success in terms of evaluation criteria}

Levels of agreement: 1=completely disagree, 2=disagree, $3=$ yes and no, 4=agree, 5=fully agree)

\begin{tabular}{|l|l|c|l|l|}
\hline $\begin{array}{c}\text { Criterion of } \\
\text { evaluation }\end{array}$ & \multicolumn{1}{|c|}{ Question /statement } & $\begin{array}{c}\text { Average of } \\
\text { rating }\end{array}$ & \multicolumn{1}{|c|}{$\begin{array}{c}\text { Sector with } \\
\text { highest average }\end{array}$} & \multicolumn{1}{|c|}{$\begin{array}{c}\text { Sector with lowest } \\
\text { average }\end{array}$} \\
\hline Relevance & $\begin{array}{l}\text { Our cluster is important for us because it satisfies } \\
\text { real existing needs }\end{array}$ & 4,14 & $\begin{array}{l}\text { Environment } \\
\text { protection }\end{array}$ & $\begin{array}{l}\text { Information and } \\
\text { communication technology }\end{array}$ \\
\hline Efficiency & Our cluster is well-organized. & 3,55 & $\begin{array}{l}\text { Information and } \\
\text { communication } \\
\text { technology }\end{array}$ & Classical manufacturing \\
\hline Effectiveness & $\begin{array}{l}\text { Our cluster is delivering the results that were } \\
\text { expected to produce up to this day. }\end{array}$ & 3,73 & $\begin{array}{l}\text { Information and } \\
\text { communication } \\
\text { technology }\end{array}$ & Classical manufacturing \\
\hline Impact & $\begin{array}{l}\text { Our cluster has had positive effects: it has generated } \\
\text { positive benefits beyond the direct benefits of } \\
\text { member companies. }\end{array}$ & 4,05 & $\begin{array}{l}\text { Information and } \\
\text { communication } \\
\text { technology }\end{array}$ & Classical manufacturing \\
\hline Sustainability & $\begin{array}{l}\text { Our cluster is able to operate without external } \\
\text { support, is expected to survive on the long term. }\end{array}$ & 3,73 & $\begin{array}{l}\text { Information and } \\
\text { communication } \\
\text { technology }\end{array}$ & Classical manufacturing \\
\hline
\end{tabular}

Source: Expert survey ( $\mathrm{N}=22$ clusters).

Success depending on regional vs. sectoral focus. There is a significant difference between regionally focused clusters as opposed to sectorally focused ones. Sectorally focused clusters, which are organised around a particular profession or technology, are perceived by their member companies as much more efficient and sustainable than clusters relying strongly on the regional principle of organisation.

The differentiation between sectorally vs. regionally focused clusters is relevant, because a significant amount of cluster subsidies is available under regionspecific subsidy schemes. This aspect of support policy was recently challenged by some successful clusters which have a presence in several regions of Hungary or even claim to have a national or international scope. veness among Hungarian clusters is whether the cluster (or one of its members) has reported about an ongoing or succesfully implemented joint innovation, research or development project. While universities are keen to report on their websites about their membership in various clusters, member companies are reporting about their cluster activity and cluster membership only in exceptional cases. In many cases it is not the cluster that runs the innovation projects, but some member company of the cluster.

However, in these latter cases the cluster provides opportunities for its members to successfully manage their innovation activities, e.g. by providing access to different funds, a knowledge base, or access to other highly competitive companies of a given sector, both in Hungary and abroad. 
The web research $(\mathrm{N}=75)$ has revealed that only about one-tenth of the investigated clusters have claimed to run a joint innovation / research / development project in and by the cluster. On the other hand about half of the investigated clusters have contributed to the spreading of innovative products or services among their member companies.

What type of innovation. A clear dominance of innovations embodied in a product or technology has been observed, as opposed to intangibles.

Product. Most innovations reported by clusters and their members are product and technology innovations. Clusters in the biotechnology, medical and IT sector frequently report about product innovations such as new drugs or a path breaking software.

Technology. A few members of the investigated clusters - with special respect to the classical manufacturing industries - have reported about innovation activites facilitating the technological process of their respective firms. Technological innovation activity is also characteristic for the environmental industry: these innovatios are embodied in new recycling technologies.

Organisational. Among intangible types of innovation, some new consultancy methods were reported.

Spreading innovation embodied in products or technologies. Clusters can be classified as moderately innovative in cases when they are not involved in direct research or development activity, but they are facilitating the spreading of innovative products and technologies. Examples: clusters importing/customising/ maintaining/promoting renewable energy generating equipment or environment friendly construction technology. About half of the clusters can be classified as moderately innovative.

Accreditation. One of the indicators of innovativeness was whether the cluster has been accredited by a Government-designated Hungarian organisation ${ }^{29}$ as an "accredited innovation cluster". The criteria of accreditation were strict, but they did not involve the issue of sustainability. Our research has found accredited innovation clusters that did not survive their first two years of existence. In 2012 there are 17 accredited innovation clusters in Hungary, 7 of which were in the sample of 75 investigated here.

Co-operation with universities and other research organisations. The web research $(\mathrm{N}=75)$ has reinforced the general impression that most (more than 80\%) of the innovative or moderately innovative clusters cooperate with some university or research institute. In particular, a provincial university in Hungary claims to co-operate with a dozen different clusters, i.e. the university was member in each of these networks. On the other hand, universities and their departments are also frequently members in clusters that are not particularly active in innovation.

The membership of a research organisation in a particular cluster does not necessarily imply that effective innovation activity is taking place. In-depth interviews have revealed that in some clusters accredited as "innovation clusters", all research and development activities have remained in the planning phase due to lack of interest on the side of the "flagship" company of the cluster - consequently due to lack of resources.

\section{Intangible drivers and barriers of inter-firm co-operation}

The expert survey has consequently demonstrated that those companies and clusters which can be characterised by a higher level of co-operation culture are more successful. In particular, respondents reporting about higher level of joint activity, learning potential and inter-firm trust within their respective clusters are also convinced that this type of networking has delivered tangible results for their firms in terms of impacts, efficiency and effectivenes.

The role of cluster identity. The identity and mission of the cluster is a very important factor of its success. Clusters with transparent aims are repeatedly reported as being more successful in terms of their impacts and effectivenes. The sustainaibility of the cluster depends very much on the coherence in its mission statement, i.e. on how the cluster defines its own identity. In particular, clusters organised around a particular product group (e.g. automobile parts), technology (e.g. waste water recycling) or knowledge (e.g. IT), and clusters organised along a particular value chain are clearly more sustainable than clusters based on a regionally available resource (e.g. labour force, thermal water, etc.) or on a particular ideology (e.g. climate change prevention).

The overwhelming majority of responding managers of clusters and member companies has

- very positive attitudes and expectations to networking and inter-firm co-operation in general,

- but their experiences with their particular cluster are mixed.

Regarding networking attitudes and expectations, most respondents have strongly agreed with the following statements ${ }^{30}$ :

- it is worthwhile to build close inter-firm relationships, and clusters provide a good framework for such co-operation,

- the advantage of strong inter-company relationships is trust that develops between the partners, 
- the more transparent are the costs and benefits of a relationship with another company, the more stable and stronger becomes the linkage,

- in our industry any well-established firm needs to build both strong and weak relationships with other companies.

Conflicts and conflict resolution capability. According to the expert survey, about one-fourth of the investigated clusters can be characterised by some hidden or open conflict. Clusters involving competitor firms, in particular in the classical manufacturing sector are more likely to face such a challenge. On the other hand, the perceived conflict resolution capability of the cluster is not significantly correlated with the prevalence of potential or open conflicts.

Culture of co-operation vs. cluster sustainability. According to the expert survey, approximately half of the respondents have stated that their cluster facilitates the culture of cooperation among its members and guarantees that all member firms are reliable business partners. Unsurprisingly, this perception correlates significantly with the existence of a common vision about the future of the cluster, in particular with an optimism regarding its sustainability.

Barriers and bottlenecks of inter-firm co-operation. In the expert survey the majority of the respondents have stated ${ }^{31}$ that the lack of financial resources is a major barrier to inter-firm co-operation. Other factors which have weakened or reduced co-operation willingness and ability are (in decreasing sequence of importance): competitor firms within the cluster, lack of legal knowledge that is necessary for managing co-operation, excessively dominant position of some firms in the cluster, lack of professional/sectoral knowledge (e.g. engineering, biology, IT, etc), lack of appropriate business services and lastly: lack of adequate research facilities.

\section{Conclusions and recommendations}

The Hungarian cluster landscape consists of relatively many business networks: approximately 180 well documented consortia refer to themselves as clusters. In international comparison this is a relatively high number and is to be expected that out of them only an elite of well organised and internationalised clusters will survive in the long term. Business networks vary widely according to the depth, professional content and quality of inter-firm co-operation. It is not easy to distinguish between autonomous, innovative, sustainable clusters on the one side, and temporary, rent-seeking consortia on the other side. The latter type has been organised only for the purpose of lobbying for regulatory advantages or solely for the purpose of applying for subsidies. Cluster policy should rely on sophisticated, internationally tested methods in order to identify those business networks which can contribute to national competitiveness and deserve support. Network analyisis should deliver the major criteria of cluster quality. The strength, structure and quality of inter-firm linkages should be promoted by carefully avoiding any distortion of competition.

\section{Footnotes}

${ }^{1}$ This is the a shortened version of the original research report. The original report has the following title: "From temporary consortia to innovation clusters: the evolution of co-operation patterns in Hungarian business networks"

2 Title of research project: "Entrepreneurial networks in Hungary". Research project implemented in 2011/2012 by the Institute for Sociology and Social Policy of Corvinus University Budapest. Supported by the TÁMOP Programme under TÁMOP-4.1.2. Members of the project team: Csilla Lukács and András Molnár (M.Sc. students at Chair of Entrepreneurship Development of Corvinus University of Budapest), Attila Varga and Edit Veres (Ph.D. students at the Doctoral School of Sociology of the Corvinus University of Budapest).

${ }^{3}$ See e.g. (OECD, 2004), (Wixted, 2006)

${ }^{4}$ See e.g. (Netwin, 2007), (Futó - Hurton, 1998), (Villa - Antonelli, 2008).

${ }^{5}$ See e.g. (Granovetter, 1985) and (Lazzarini - Zenger, 2007).

${ }^{6}$ The early predecessors of this type of research were the investigation about strategic alliances among Hungarian firms, see (Tari, 1998) and (Buzády, 2000).

7 (Futó - Soltész - Lányi, 2003)

${ }^{8}$ According to our desk research, out of the 20 clusters and business networks surveyed in 2003, only 4 survived into 2011, all of the surviving clusters / networks being active in the manufacturing sector.

${ }^{9}$ (Kohegyi, 2005)

${ }^{10}$ (EU, 2006)

${ }^{11}$ (Netwin, 2007)

12 (Szanyi et al., 2010)

${ }^{13}$ This "meso-level" approach to cluster identification is different from the "micro-level", "organisational" approach taken in this research.

${ }^{14}$ (Szanyi, 2008a) (Szanyi, 2008b)

${ }^{15}$ See e.g. (Futó, 1998)

${ }^{16}$ E.g. to introduce ISO 9000 Quality Management Systems

${ }^{17}$ In 2001 and 2002 the Government has disbursed subsidies under the so called "Széchenyi Terv" for 36 beneficiary consortia. Analogous subsidies were launched in 2003 within the so called "Széchenyi Vállalkozásfejlesztési Program" (Széchenyi Entrepreneurship Programme, in 2005 and 2006 in the "Gazdasági Versenyképesség Operatív programme" (Economic Competitiveness Operative Program), furthermore in 2008-2011 under the "Regional Operative Programmes" and in the so called "Pólus Program" under the "New Hungary Development Plan".

${ }^{18}$ Source: presentation of Mr Peter Keller, Head of Department at Mag Zrt (Hungarian Economic Development Centre Ltd) at the Cluster Conference held in Budapest, 22. February 2012. 
${ }^{19}$ Source: presentation of Mr Peter Keller, Head of Department at Mag Zrt (Hungarian Economic Development Centre Ltd) at the Cluster Conference held in Budapest, 22. February 2012.

${ }^{20} \mathrm{See}$ http://www.polusprogram.eu and http://en.magzrt.hu/

${ }^{21}$ Source: http://www.polusprogram.eu and http://en.magzrt.hu/

${ }^{22}$ Note: The number of accredited clusters is continuously changing due to the expiration and renewal of accreditation diplomas.

${ }^{23}$ Source: Interview with Ms Orsolya Szentpéteri, Secretary General of the Hungarian Alliance of Clusters. For more details of the EU-wide initiative "Cluster Excellence" see: http://www. cluster-excellence.eu/

${ }^{24}$ Own calculations, based on the online database http://www.clusterobservatory.eu/. In February 2012 the website of the project "European Cluster Observatory" reports about the existence of altoghether 118 cluster organisations in Hungary, 42 in Austria, 1 in Croatia,10 in Romania, 3 in Serbia, 13 in Slovakia and 15 in Slovenia.

${ }^{25}$ Hungary consists of 19 counties plus the capital Budapest.

${ }^{26}$ (Netwin, 2007)

${ }^{27}$ (Dobronyi - Halmos - Somosi, 2011)

${ }^{28}$ See e.g. (EU, 2004)

29 „Pólus Akkreditációs Testület”, i.e. Pólus Accreditation Body established in 2008 and its legal successor, the MAG - Hungarian Economic Development Centre (MAG). Accredited clusters have certain advantages when participating in tenders, e.g. are eligible to participate in restricted tenders.

${ }^{30}$ Strong agreement was indicated by a rating of 5 on a scale ranging from 1 to 5 . This bulleted list contains statements for which the average rating of agreement was higher than 4 and the dispersion was lower than 1 .

${ }^{31}$ These respondents have agreed on a level of 4 or 5 with the following statement „In our cluster the potential for co-operation is reduced by the fact that there is a lack of money and resources allocated for enhancing co-operation."

Peter Futo - Affiliate Professor, Corvinus University of Budapest, Centre for Local Development Research

\section{References}

Buzády (2000): Stratégiai szövetségek Magyarországon. (Business Strategic Alliances in Hungary). Ph.D. dissertation. Budapest: Budapesti Közgazdaságtudományi és Államigazgatási Egyetem

Dobronyi T.-Halmos L. -Somosi É. (2011): Klasztermenedzsment - Magyarország. Budapest: Complex Kiadó

$E U$ (2004): Project Cycle Management Guidelines. Volume 1 of the series "Aid Delivery Methods / Supporting effective implementation of EC External Assistance. Brussels: European Commission, EuropeAid Cooperation Office

EU (2006): Innovation clusters in the 10 new Member States of the European Union. Christian Ketels, Örjan Sölvell. With contributions from Emiliano Duch, Inés Sagrario, Torbjörn Folkesson and Göran Lindqvist. Prepared by Europe Innova. Brussels: European Communities

EU (2007): Innovation clusters in Europe. A statistical analysis and overview of current policy support. Europe Innova / PRO INNO Europe paper $N^{\circ}$ 5. DG Enterprise and Industry report. Brussels: European Communities
$E U$ (2008): The concept of clusters and cluster policies and their role for competitiveness and innovation: main statistical results and lessons learned. Europe INNOVA / PRO INNO Europe paper $\mathrm{N}^{\circ}$ 9. Annex to the Communication from the Commission "Towards worldclass clusters in the European Union: Implementing the broad-based innovation strategy" Brussels: European Commission

Futó P. (1995): Alvállalkozók - beszállítók nemzetközi összehasonlításban (Subcontractors in international comparison). Statisztikai Szemle, 2. sz.: p. 155-165.

Futó P. (1998): Supporting subcontracting linkages in Hungary. Small Enterprise Development, 4.: p. 46-55.

Futó P. (2011): Evaluation and Impact Assessment of Business Climate Development. With case studies from Small Business Development Policy and Regulatory Policy. Budapest: Institute of Sociology and Social Policy, Corvinus University. Research supported by the Hungarian 'Social Renewal Operational Programme' (Társadalmi megújulás operatív program)

Futó P, - Hurton E. (1998): A vállalatok közti kapcsolatokról (On inter-company relations). Vezetéstudomány (Management Science), No. 1: p. 10-15.

Futó - Soltész - Lányi (2003): Regionális klaszterek és a létesítésükre, múködtetésükre vonatkozó politikák Magyarországon. Budapest: SEED

Granovetter, M. (1985): Economic action and social structure: the problem of embeddedness. American Journal of Sociology, 91: p. 481-510.

King, G. - Keohane, R.O. - Verba, S. (1996): Designing Social Inquiry: Scientific Inference in Qualitative Research. Princeton: Princeton University Press

Kőhegyi K. (2005): Entrepreneurial networks (Vállalkozói hálózatok). Közgazdasági Szemle, LII. évf., 2005. május: p. 480-493.

Lazzarini, S.G. - Zenger, T.R. (2007): The Strength of Churning Ties: Tie Portfolios, Tie Interdependence, and the Dynamics of Interorganizational Relationships. August

Netwin (2007): Klaszterek Magyarországon - fejlődési kilátásaik, szerepük a KKV-k fejlődésében, növekedésében. Készítette: Netwin Üzleti Tanácsadó Kft. A tanulmány a Nemzeti Kutatási és Technológiai Hivatal támogatásával készült. Budapest: Netwin

Observatory (2003): SMEs and co-operation. Observatory of European SMEs, 2003, No. 5. Published by the European Commission. Report submitted to the Enterprise DirectorateGeneral of the European Commission by KPMG Special Services and EIM Business \& Policy Research in the Netherlands, in co-operation with the European Network for SME Research (ENSR), and Intomart

OECD (1999): Boosting Innovation: The Cluster Approach. Paris: OECD

OECD (2004): Networks, Partnerships, Clusters and Intellectual Property Rights: Opportunities and Challenges for Innovative SMEes in a Global Economy. OECD. Presented: 2nd OECD Conference of Ministers 
Responsible for Small and Medium-Sized Enterprises. Istanbul, Turkey 3-5 June

Porter, M. (1980): Competitive Advantage: Creating and Sustaining Superior Performance. New York: Free Press

Sornn-Friese, H. - Simoni Sørensen, J. (2011): Linkage lockin and regional economic development: the case of the Øresund medi-tech plastic industry. Entrepreneurship and Regional Development, 2005, vol. 17, No. 4 (July): p. 267-291.

Szanyi, M. - I. Iwasaki - Csizmadia, P. - Illéssy, M. - Makó, Cs. (2010): Emergence and Development of Industry Clusters in Hungary. Searching for a 'Critical Mass' of Business via Cluster Mapping. Discussion Paper Series A No.539. Institute of Economic Research, Hitotsubashi University, Kunitachi, Tokyo, 186-8603 Japan. May

Szanyi M. (2008a): Klaszterekról a pólusprogram kapcsán. MTA Világgazdasági Kutatóintézet, Kihívások, No. 191.
Szanyi M. (2008b): A versenyképesség javítása együttmúködéssel. Regionális klaszterek. Bp.: Napvilág Kiadó

Tari E. (1998): Stratégiai szövetségek az üzleti világban (Business Strategic Alliances). Budapest: KJK

The Economist (2011): Italian industry. Clusters flustered. Global competition seems to be weakening the benefits of being in a cluster. Case studies of Italian clusters: Castellanza, San Maurizio D'Opaglio and Valenza. The Economist, Apr 14th

Villa, A. - Antonelli, D. (eds.) (2008): A Road Map to the Development of European SME Networks. Towards Collaborative Innovation. London: Springer

Wixted, B. (2006): Cluster Complexes: A Framework for Understanding the Internationalisation of Innovation Systems. October 2006. MPRA Paper No. 846.

Article provided: 2012.7.

Article accepted: 2013. 3.

\section{Szerzôinknek}

A Vezetéstudomány a Budapesti Corvinus Egyetem Gazdálkodástudományi Karának havi, referált folyóirata. A lapban a vezetési és gazdálkodási tudományterületekhez kapcsolódó témakörök elméleti és gyakorlati kérdéseit elemzó és vizsgáló írások jelennek meg. A szerkesztőség (sandorkerekes@unicorvinus.hu) elektronikus formában kéri az írásokat.

A cikkeket elektronikus levélben (MS Word fájl formátumban) lehet a szerkesztóséghez eljuttatni. A Vezetéstudományban megjelent cikkek magyar és angol nyelvú összefoglalói elérhetóek a http://www.vezetestudomany.hu és a http:// vezetestudomany.hu címeken.

A lap tudományos folyóirat, ezért szövegközi forráshivatkozások és ezek jegyzéke nélküli írásokat nem jelentet meg. A Vezetéstudományban megjelentetni szándékozott kéziratok szerzôitôl az alábbi követelmények figyelembevételét kérjük:

- A cikkek szokásos terjedelme a hivatkozásokkal, ábrákkal és táblázatokkal együtt 20-24 oldal, 1,5-es sortávolsággal (12-es betúméret, Times New Roman betütípus).

- A cikkek elsó oldalának alján tüntessék fel a szerzó foglalkozását, munkahelyét és beosztását, elektronikus levelezési címét, a tanulmány elkészítésével kapcsolatos információkat és az esetleges köszönetnyilvánításokat.

- A kézirathoz csatolandó egy magyar nyelvú és lehetőség szerint egy angol nyelvú rövid összefoglaló (200 szót nem meghaladó terjedelemben), valamint a cikk fő témaköreit megnevezó kulcsszavak jegyzéke.

- Kiemeléshez félkövér és dólt betú használható, aláhúzás nem. Jegyzeteket lehetóleg ne használjanak, amennyiben azok feltétlenül szükségesek, szövegvégi jegyzetként adják meg.

- A táblázatoknak és ábráknak legyen sorszáma és címe, valamint - átvett forrás esetén - pontos hivatkozása.

- Az ábrákat és a táblázatokat a kézirat végén, külön oldalakon, sorszámmal és címmel ellátva kérjük csatolni, helyüket a szövegben egyértelmúen jelölve (pl. ,Kérem az 1. táblázatot kb. itt elhelyezni!”).

- A szövegközi bibliográfiai hivatkozásokat zárójelben, a vezetéknév és az évszám feltüntetésével kérjük jelölni: pl.
(Veress, 1999); szó szerinti, idézőjeles hivatkozás esetén kiegészítve az oldal(ak) számával (pl. Prahalad - Hamel, 1990: 85.).

- Amennyiben egy hivatkozott szerzónek több bibliográfiai tétele van ugyanazon évben, ezeket 1999a, 1999b stb. módon kell megkülönböztetni.

- A felhasznált források cikk végén elhelyezett jegyzékét ábécérendben kérjük, a következó formában:

1. példa (könyv): Porter, M.E. (1980): Competitive Strategy; New York: The Free Press

2. példa (folyóiratcikk): Prahalad, C.K. - Hamel, G. (1990): The Core Competence of the Corporation; Harvard Business Review, május-június, 79-91. o.

A formai követelmények fentiekben érvényesített, ún. „Harvard” rendszeréról (más néven „szerzólév” vagy „név/dátum” hivatkozási módszerról) részletes tájékoztatást nyújtanak az alábbi WEB-címeken elérhető források:

http://education.exeter.ac.uk/dll/studyskills/harvard_referencing.htm http://sydney.edu.au/library/subjects/downloads/citation/Harvard_ Complete.pdf

Havi folyóirat lévén és a megjelenés átfutási idejének csökkentése érdekében a Vezetéstudomány kefelevonatot nem küld, elfogadás elótt azonban a szerzóknek egyeztetés céljából elküldi a cikk szerkesztett változatát.

2009. januártól a Vezetéstudományban publikált cikkek elérhetőek az ISI Eme ,www.securities.com” internetcímen található strukturált on-line információs adatbázisban. 2009 júniusától a Vezetéstudományban közölt írások elérhetőek az EBSCO Academic Search Complete adatbázisában a http:// web.ebscohost.com/ehost/search $?$ vid $=20 \&$ hid $=102 \&$ sid $=747$ a 76 4f-362f-4683-9255-4e54f5ba0df $7 \% 40$ sessionmgr 112 oldalon is.

2012. március 1-jétól a Vezetéstudomány egyes cikkei elérhetőek a http://unipub.lib.uni-corvinus.hu/500/ oldalon is.

Külön kívánságra 2004-ig visszamenóleg az összes korábbi kiadás publikációit elektronikus változatban is elküldjük. Ha a szerző nem járul hozzá cikkének eseti kérésre, elektronikus úton való továbbadásához, kérjük, eloore közölje ezt. 